\title{
REGIONAL CONVERGENCE IN THE EUROPEAN UNION, NEW MEMBER STATES AND CROATIA
}

Davor Mikulić, Željko Lovrinčević, Andrea Galić Nagyszombaty *

\begin{abstract}
Over the past two decades, the issue of regional convergence in the European Union has been the subject of a wide range of empirical research. This paper aims to provide more information on the differences in regional growth patterns of new member states (NMS), as well as Croatia, in addition to the factors influencing regional disparities within each country. This research provides an analysis of regional convergence in the period 2001-2008 at the NUTS II and NUTS III level.

The most widely used model for testing convergence hypotheses is beta-convergence analysis. Other factors commonly included in the econometric modelling of convergence are demographic variables, labour market conditions, industrial structure, institutional factors and overall government policy. The main hypothesis is that the process of regional convergence in NMS and Croatia is not strong enough to dominate over other factors, influencing regional potential growth (mainly industry structure and quality of human capital). Absolute $\beta$-convergence can be found at the national level for $E U$ countries. Convergence also can be found for NMS regions, but the pace of convergence on the regional level is lower in comparison to the national level and the estimated $\beta$-convergence parameter is less significant.
\end{abstract}

Keywords: regional convergence, regional policy, economic growth, Croatia

\section{JEL classification: R11}

South East European Journal of Economics and Business Volume 8 (1) 2013, 9-21

DOI: $10.2478 /$ jeb-2013-0001

\section{INTRODUCTION}

Regional disparities in economic development are more evident in the European Union in comparison to other developed economies such as USA or Japan, particularly after the recent waves of EU enlargement. The most developed EU regions are approximately eight times richer than the least developed regions. Due to significant differences in regional development, the EU introduced a set of policy measures to promote the integration and convergence of less developed areas among the Member States.

While data on regional disparities in the EU shows recent improvements, all new member states show increasing 'dispersion within country' ${ }^{1}$ over the analyzed period. In the period 2000-2008, Croatia, besides Latvia and Portugal,

\footnotetext{
The dispersion of regional per capita GDP (at NUTS 3 level) is measured by the sum of the absolute differences between regional and national GDP per capita, weighted with the share of population and expressed in percent of the national GDP per capita. The indicator is calculated from Eurostat regional GDP figures based on the European System of Accounts (ESA95). The dispersion of regional GDP is zero when the GDP per capita in all regions of a country is identical, and it rises if there is an increase in the distance between a region's GDP per capita and the country mean.
}

recorded the lowest change in regional dispersion (1.5) in comparison to NMS.

Theoretical and empirical research on regional income convergence has become especially popular over the last two decades. The first studies on convergence were presented in Baumol (1986) and Barro and Sala-i-Martin (1991). The

\section{* Davor Mikulić, Ph. D.}

Senior research fellow

Institute of Economics, Zagreb

E-mail: dmikulic@eizg.hr

\section{Željko Lovrinčević, Ph. D.}

Senior research fellow

Institute of Economics, Zagreb

E-mail: zlovrincevic@eizg.hr

Andrea Galić Nagyszombaty, M. Sc.

Head of Department

Central Bureau of Statistics of the Republic of Croatia

E-mail: galica@dzs.hr 
Table 1. Dispersion of regional GDP per inhabitant in EU member states and Croatia

\begin{tabular}{|c|c|c|c|c|c|c|c|c|c|}
\hline & 2001 & 2002 & 2003 & 2004 & 2005 & 2006 & 2007 & 2008 & $\begin{array}{l}\text { Difference } \\
2008-2001\end{array}$ \\
\hline EU (27 countries) & 35.3 & 34.6 & 34.1 & 33.4 & 33.1 & 33.0 & 32.6 & 32.2 & -3.1 \\
\hline \multicolumn{10}{|l|}{ OLD MS } \\
\hline Belgium & 28.4 & 28.4 & 27.8 & 28.1 & 28.3 & 27.8 & 27.9 & 27.2 & -1.2 \\
\hline Czech Republic & 24.3 & 24.9 & 25.0 & 24.2 & 25.0 & 25.4 & 26.6 & 26.8 & 2.5 \\
\hline Germany & 29.4 & 29.1 & 29.3 & 29.1 & 28.8 & 28.7 & 28.4 & 27.8 & -1.6 \\
\hline Austria & 26.3 & 26.1 & 25.7 & 24.8 & 24.6 & 24.3 & 23.6 & 23.3 & -3.0 \\
\hline Finland & 32.7 & 31.7 & 29.8 & 29.5 & 29.9 & 30.4 & 30.3 & 30.0 & -2.7 \\
\hline Ireland & 23.7 & 26.9 & 27.5 & 26.4 & 27.9 & 28.6 & 29.3 & 30.0 & 6.3 \\
\hline Spain & 21.1 & 20.5 & 19.8 & 19.4 & 19.1 & 19.1 & 18.8 & 18.8 & -2.3 \\
\hline France & 23.8 & 23.5 & 23.6 & 22.6 & 23.2 & 23.1 & 23.7 & 23.9 & 0.1 \\
\hline Italy & 26.0 & 25.6 & 25.4 & 25.5 & 25.0 & 24.4 & 24.2 & 24.2 & -1.8 \\
\hline Sweden & 14.9 & 15.2 & 14.9 & 15.7 & 16.2 & 15.2 & 15.5 & 15.9 & 1.0 \\
\hline United Kingdom & 27.2 & 27.9 & 27.9 & 27.4 & 27.4 & 28.0 & 28.9 & 30.7 & 3.5 \\
\hline \multicolumn{10}{|l|}{ NMS } \\
\hline Bulgaria & 28.8 & 30.1 & 30.2 & 30.9 & 32.9 & 38.0 & 42.7 & 44.3 & 15.5 \\
\hline Estonia & 37.2 & 38.6 & 41.3 & 42.3 & 39.6 & 43.4 & 41.4 & 41.0 & 3.8 \\
\hline Poland & 31.1 & 32.7 & 32.4 & 32.2 & 33.3 & 34.3 & 34.5 & 33.3 & 2.2 \\
\hline Portugal & 27.5 & 27.8 & 28.3 & 28.8 & 29.3 & 28.6 & 28.9 & 28.9 & 1.4 \\
\hline Romania & 27.9 & 30.1 & 29.3 & 29.2 & 33.7 & 34.4 & 35.2 & 37.7 & 9.8 \\
\hline Slovenia & 20.1 & 20.5 & 22.3 & 21.9 & 21.8 & 22.3 & 22.4 & 21.8 & 1.7 \\
\hline Slovakia & 27.3 & 28.1 & 28.7 & 29.2 & 33.7 & 34.4 & 35.0 & 32.7 & 5.4 \\
\hline Latvia & 45.2 & 51.9 & 49.0 & 52.9 & 51.3 & 46.9 & 45.6 & 45.3 & 0.1 \\
\hline Lithuania & 21.8 & 24.7 & 24.2 & 23.7 & 25.1 & 27.6 & 29.0 & 28.0 & 6.2 \\
\hline Hungary & 37.6 & 39.6 & 37.7 & 37.9 & 40.2 & 42.5 & 42.4 & 42.8 & 5.2 \\
\hline Croatia & 29.6 & 28.5 & 31.0 & 31.9 & 32.9 & 33.8 & 32.8 & 31.1 & 1.5 \\
\hline
\end{tabular}

Source: Eurostat database (downloaded in 2012).

broad literature on convergence is mainly concerned with three well-known competitive convergence hypotheses:

- the absolute (unconditional) convergence hypothesis

- the conditional convergence hypothesis

- the club convergence hypothesis

According to the absolute convergence hypothesis, the per capita incomes of countries or regions converge with one another in the long-term regardless of other initial conditions. The traditional and widely used tool for testing convergence hypotheses is beta-convergence analysis. Beta-convergence ( $\beta$-convergence) is defined as a negative relationship between initial income level and growth rate, and implies that all economies converge at the same unique and stable steady state equilibrium. The theoretical background for this hypothesis is found in traditional neoclassical growth theory, stating that economic growth depends on the three main production factors: population, capital accumulation and technology. As more capital is engaged in more developed regions, lower marginal returns to capital and slower economic growth are to be expected. Globalization and international trade, as well as migration and liberalization of international capital flows, are factors in favor of reducing the productivity gap and living standards between countries and regions.

While some empirical research confirms the unconditional convergence hypothesis, the majority of this research employs a homogeneous sample of countries or regions. The absolute $\beta$-convergence hypothesis is usually tested by the following cross-sectional econometric equation (Baumont et al 2002):

$$
\mathrm{gt}=\alpha \mathrm{S}+\beta \mathrm{y} 0+\varepsilon,
$$

where gt is the $(n * 1)$ vector of per capita GDP average growth rate (where $\mathrm{n}$ is the number of regions) in the period $(0, t)$; $y 0$ is the vector of per capita GDP initial levels (at time 0$) ; S$ is the unit vector and $\varepsilon$ is the vector of error terms. The absolute convergence hypothesis is confirmed if the estimate of coefficient beta is statistically significant and negative.

The conditional convergence hypothesis assumes that in the long run per capita incomes of economies converge with one another if the main features of those economies are similar. The technological levels of economies, their socio-demographic features (such as educational levels and population growth) and overall institutional environment are the main factors which are assumed to be similar as a prerequisite for convergence. If those factors differ among economies, each particular economy will tend to reach its own unique equilibrium. The evidence should suggest the existence of conditional convergence if the negative relationship between initial per capita incomes and their 
growth rates holds only after the possibility of the abovementioned structural characteristics has been controlled for (Mankiw et al 1995). The cross-sectional equation for testing conditional $\beta$-convergence is as follows, in matrix form (Baumont et al 2002):

$$
\mathrm{g}=\alpha \mathrm{S}+\beta \mathrm{y}+\mathrm{X} \varphi+\varepsilon
$$

where $\mathrm{X}$ is the matrix of explanatory variables constant in the steady state equilibrium and all other terms are as previously defined. There exists conditional $\beta$-convergence if the estimated value for $\beta$ is significantly negative even after controlling for other initial factors.

In addition to the conditional and unconditional convergence hypothesis, Fischer and Stirböck (2004) define club convergence as the process by which each region belonging to a certain club moves from a disequilibrium position to its club-specific steady-state position. At the steady-state the growth rate is the same across the regional economies of a club. Cappelen (2001) notes that the concept of club convergence is not relevant in the context of standard neoclassical models because the agents are assumed to be homogeneous. This assumption would mean that there are no different initial conditions and therefore no club convergence. However, if the agents are allowed to be heterogeneous the dynamic system of the neoclassical growth model could lead to multiple steady-state equilibrium in spite of diminishing returns to capital. Durlauf (2001) points out that a key limitation of the majority of empirical analyses of cross-sectional regional growth has been that the assumption of a single steady-state has to hold for all the regional economies in the sample, which is the case for absolute and conditional convergence hypotheses. The club convergence hypothesis, on the other hand, allows multiple and local stable steady-state equilibriums only. The sigma-convergence approach has become popular following the work by Quah (1993) showing that the traditional negative relationship between economic growth and initial development level does not provide a unique answer in terms of convergence. According to the author, the relationship tends to be negative even if income differences have not decreased. Sigmaconvergence ( $\sigma$-convergence) pertains to the decline in the cross-sectional dispersion of per capita incomes over time.

Paas and Schlitte (2007) highlighted the theoretical background for the convergence/divergence process. According to neoclassical growth theory, the decrease of disparities in income levels is expected because of decreasing returns to capital. On the other hand, endogenous growth theory predicts stable or even increasing inequality due to increasing returns to scale. According to the endogenous growth theory, policy measures can have a long-term impact on the growth rate of an economy, while in the neoclassical model long-term growth can be established only by a change in the savings rate. In addition to mainstream theories, North (1990) shows that institutions are the stimulating systems of a society which can both promote and slow economic growth. Less developed regions can therefore grow and catch up with developed regions only if efficient institutions are developed.

\section{RECENT EMPRIRICAL STUDIES ON REGIONAL CONVERGENCE IN THE EUROPEAN UNION}

In addition to the theoretical research, convergence hypothesis has been broadly empirically tested in recent literature. Barro and Sala-i-Martin (1991), analyzing 73 European regions (since 1950) and 48 USA states (since 1880) found the existence of convergence in both samples. In the USA, over a long time period, less developed states tend to growth faster in per-capita terms in comparison to richer states even if other relevant variables are not considered constant. On the other hand, for the group of European countries, conditional convergence was found after controlling for factors of initial productivity and the rate of technological progress. In further research, Sala-i-Martin (1996) included Japanese prefectures and Canadian provinces and concluded that regions tend to converge at a speed of approximately two percent per year, which resulted in diminishing interregional dispersion of income over time. The convergence process in the USA has been subject of interest in Rey (1998) and Tsionas (2000). While Rey (1998) found strong patterns of global and local spatial autocorrelation, Tsionas (2000) concluded that regional income in USA has not converged over the sample period (1977-1996).

The remainder of the paper is mainly concerned with convergence studies in the EU. In the majority of studies there is agreement that regional income convergence has been recorded in Europe from the 1950s to the 1970s. After that period the convergence process is less obvious, although some studies found evidence of further convergence.

Neven and Gouyette (1994) analyzed the growth of European economies in the period 1975-1990 and pointed to the differences in convergence trends across sub-periods and across the subsets of regions. In the first half of the 1980s, they found a divergence pattern in Northern Europe, while after that period clear and strong convergence can be found. Regions in Southern Europe converged at the beginning of the period and stagnated thereafter.

Lopez-Bazo et al. (1997) found fast and continuous convergence in productivity for $129 \mathrm{EU}$ regions in the period 1983-1992. On the other hand, they found no clear evidence of convergence in living standards measured by GDP per capita. According to the authors, the factors behind those results are trade liberalization and the need for firms to achieve common competitiveness standards. Firms which have not succeeded in that process have been forced to reduce costs by reducing the number of employees and eventually exit the market. Consequently, less developed regions have suffered from higher unemployment rates. The authors concluded that EU regional policy has a direct impact on labour productivity, but its effects on per capita GDP are less evident.

Boumont et al. (2002) using a sample of 138 European regions over the period 1980-1995 conclude that spatial dependence and spatial heterogeneity really matter in the estimation of beta convergence processes. They found that the convergence process varies across areas. The convergence process could not be identified for northern regions, while there is some evidence of convergence for southern 
regions. They also estimated a spatial spillover effect in the European regions and found this effect to be strongly significant, meaning that the growth rate in a certain region is positively affected by the average growth rate of neighboring regions.

Arbia, Basile and Piras (2005) found spatial autocorrelation through a regional interaction effect using a sample of 92 Italian provinces between 1951 and 2000, although the speed of convergence estimated by the spatial lag model is lower in comparison to the speed resulting from classical fixed-effect specification. Arbia and Piras (2005) conducted similar research on 125 regions of 10 European countries for the period 1980-1995 and concluded that taking into account the spatial dependence among the units resulted in slower convergence, but the beta coefficient is still significant and negative. Using micro-data for the Czech Republic, Hungary, Poland and Russia, Foster, Jesuit and Smeeding (2005) found that regional income inequality is increasing. Capital cities and major urban areas which are generally the most developed areas recorded higher growth of income, while poorer areas lagged behind.

Paas and Shclitte (2007), based on beta-convergence analysis during the period 1995-2002, concluded that the speed of regional income convergence processes in EU was relatively slow. According to their analyses the average speed of absolute convergence was higher for the EU15 than for the NMS. Using models with country dummies they found evidence for conditional convergence (models with country dummies) neither between the EU15 regions nor the NMS regions. At the same time, for the new member states conditional divergence can be found and regional disparities increased. These findings imply that despite an overall convergence in the EU (among countries), there was no convergence within individual countries.

Checherita, Nickel and Rother (2009) analyzed the convergence process and the role of fiscal transfers in EU for the period 1995-2005. They concluded that there has been a process of convergence across the European regions in terms of both per-capita output and income. Like Paas et al. (2007), they also concluded that convergence within each individual country is noticeably more limited, although it can be found in Italy. Disposable income across European regions converges during the analyzed period at a higher speed than primary income. At the same time, output per capita converged slower than primary income. As the main difference between GDP per capita and household primary income per capita is explained by the commuting flows of workers, the authors concluded that labour mobility appears to be particularly important for the process of income adjustment.

Melchior (2009) presented the results on within-country regional inequality in per capita income for 36 mainly European countries during 1995-2005. He found that there was a significant increase in regional inequality in 23 out of the 36 analyzed countries, while a reduction in inequality was present in only three countries. Similar to the abovementioned research, inequality increased in all Central and Eastern Europe countries. On the other hand, no evident change was recorded for the group of old EU member states.
The process of regional economic developments in Croatia has been limited, with few pieces of research primarily focusing on related issues, such as unemployment, the formulation of regional policy or the role of public investments. Botrić (2003) tried to answer the question of whether regional differences in unemployment rates are region specific or under the influence of nation-wide shocks. The results imply that some of the regions are influenced by region-specific shocks. Those regions have developed their own trends, which might lead to persistent and even increasing unemployment rates, which, in turn, could be a significant problem for regions with already high unemployment.

Maleković, Puljiz and Tišma (2011) find that the NMS integration process inevitably brings new opportunities and challenges, both on local and regional levels. Besides opportunities for the funding of development projects, the authors outline other advantages in the context of increasing the speed of convergence. These benefits include the process of institution building, a more active approach in formulating national policy frameworks, and the creation of new cooperation.

Drezgić (2011) studied variations in regional growth rates in Croatia, attempting to identify the proportion of difference in growth which could be attributed to regional level capital accumulation. The results showed that the regional disparities in Croatia intensified in the period of increased government investment activity.

\section{ECONOMIC DISPARITIES IN THE EUROPEAN UNION, NEW MEMBER STATES AND CROATIA}

This chapter presents an overview of basic economic indicators for EU, the NMS NUTS II regions and Croatian counties. As can be seen, in base year (2000) GDP per capita ${ }^{2}$ was highest in Luxembourg (244.9), followed by Netherlands (134.1), Denmark (131.5) and Austria (131.2). With a 49.6 GDP per capita, Croatia is in the group of less developed countries. It is obvious that Romania (26.0) and Bulgaria (28.4) have the lowest GDP per capita in the EU 27. The highest average annual growth of GDP per capita is registered in new member states - Romania (9.9), Lithuania (6.9), Latvia (6.7) and Bulgaria (6.6). On the other hand, in the period 20002008 the lowest average annual growth of GDP per capita $(-1.4)$ was recorded in Italy. The average annual growth of GDP per capita in Croatia was 3.3\%.

Figure 1 presents differences in the convergence process for EU countries, the NUTS II regions of new member states and Croatian counties. The data show a clear negative relation between initial development level and growth in the EU 27. While a weak relationship can be found for NMS regions, there is no relationship in the Croatian case.

Apart from initial GDP level, economic literature on convergence identifies other relevant variables in order to account for differences in development, such as economic structure, education and fixed capital. Those additional variables are presented in Tables 2-4.

\footnotetext{
Expressed in PPS, EU 27 $=100$.
} 
Figure 1. Initial development level and growth, EU, new member states and Croatia
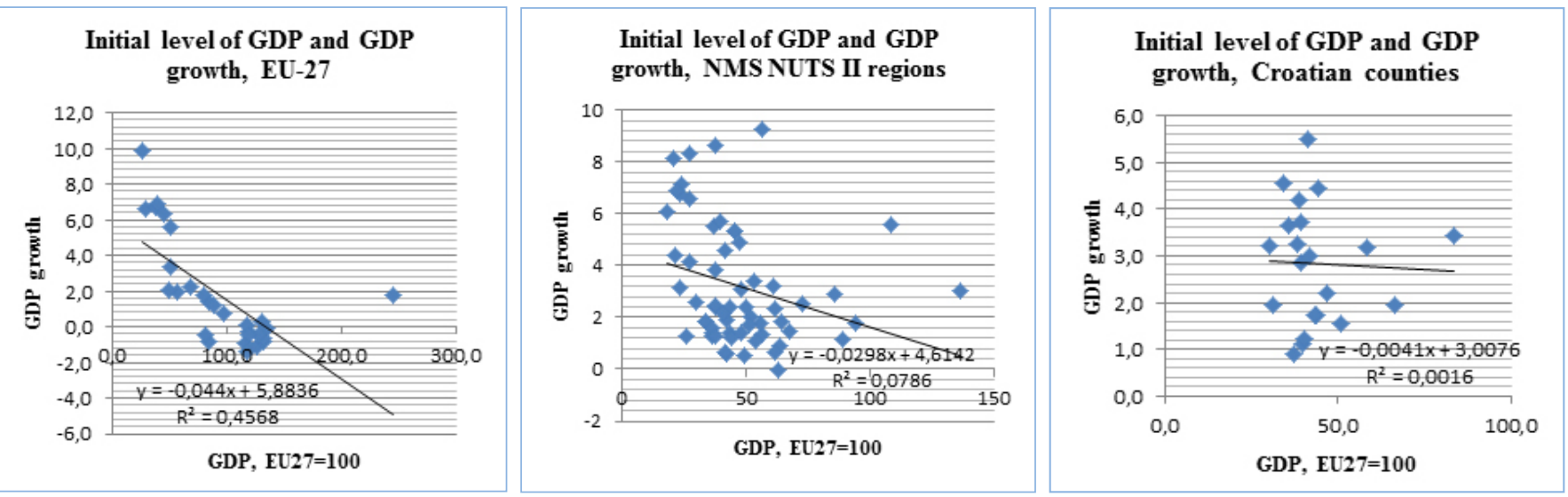

Source: Eurostat database and authors' calculations.

Table 2. Initial level of GDP, average annual growth rate and structural features of economic development

\begin{tabular}{|c|c|c|c|c|c|c|c|}
\hline & $\begin{array}{l}\text { GDP, p.c. } \\
\text { EU27=100, } \\
2000 .\end{array}$ & $\begin{array}{l}\text { Average } \\
\text { annual } \\
\text { growth of } \\
\text { GDP, p.c., } \\
2000-2008\end{array}$ & $\begin{array}{c}\text { Services, } \\
\text { as \% of GVA }\end{array}$ & $\begin{array}{l}\text { Agriculture, } \\
\text { as \% of GVA }\end{array}$ & $\begin{array}{c}\text { Industry, } \\
\text { as \% of GVA }\end{array}$ & $\begin{array}{l}\text { Investment, } \\
\text { as } \% \text { of GDP }\end{array}$ & $\begin{array}{l}\text { Pupils and Students in all } \\
\text { levels of education (ISCED* } \\
0-6 \text { ) - as \% of total popula- } \\
\text { tion at regional level }\end{array}$ \\
\hline Belgium & 126.0 & -1.1 & 74.2 & 1.0 & 24.8 & 20.6 & 26.7 \\
\hline Bulgaria & 28.4 & 6.6 & 61.4 & 10.0 & 28.6 & 23.0 & 17.7 \\
\hline Czech Republic & 68.4 & 2.2 & 59.2 & 3.1 & 37.7 & 27.0 & 20.7 \\
\hline Denmark & 131.5 & -0.8 & 72.5 & 1.9 & 25.7 & 20.2 & 25.6 \\
\hline Germany & 118.4 & -0.3 & 69.4 & 1.0 & 29.6 & 18.6 & 20.0 \\
\hline Estonia & 45.1 & 6.3 & 67.5 & 3.8 & 28.7 & 30.8 & 22.9 \\
\hline Ireland & 130.4 & 0.3 & 60.8 & 2.0 & 37.1 & 23.9 & 24.0 \\
\hline Greece & 84.0 & 1.4 & 75.6 & 4.9 & 19.4 & 22.4 & 19.2 \\
\hline Spain & 97.3 & 0.8 & 67.3 & 3.5 & 29.2 & 28.1 & 20.5 \\
\hline France & 115.2 & -0.9 & 76.3 & 2.4 & 21.2 & 19.4 & 23.2 \\
\hline Italy & 116.7 & -1.4 & 70.1 & 2.4 & 27.5 & 20.9 & 18.7 \\
\hline Cyprus & 88.7 & 1.2 & 77.9 & 3.0 & 19.1 & 19.4 & 21.4 \\
\hline Latvia & 36.7 & 6.7 & 73.3 & 4.0 & 22.6 & 28.2 & 22.0 \\
\hline Lithuania & 39.3 & 6.9 & 63.5 & 4.9 & 31.6 & 22.8 & 24.5 \\
\hline Luxembourg & 244.9 & 1.8 & 82.4 & 0.5 & 17.1 & 21.2 & 19.6 \\
\hline Hungary & 55.8 & 1.9 & 65.3 & 4.5 & 30.1 & 22.7 & 19.6 \\
\hline Malta & 83.5 & -0.9 & 73.8 & 2.6 & 23.6 & 20.1 & 20.1 \\
\hline Netherlands & 134.1 & -0.1 & 73.3 & 2.2 & 24.5 & 20.0 & 23.0 \\
\hline Austria & 131.2 & -0.7 & 68.3 & 1.8 & 29.9 & 22.3 & 20.4 \\
\hline Poland & 48.2 & 2.1 & 65.6 & 4.5 & 29.9 & 20.1 & 23.7 \\
\hline Portugal & 81.0 & -0.5 & 71.0 & 3.0 & 26.0 & 24.1 & 22.4 \\
\hline Romania & 26.0 & 9.9 & 53.3 & 11.0 & 35.8 & 23.9 & 21.2 \\
\hline Slovenia & 79.7 & 1.8 & 62.5 & 2.8 & 34.7 & 25.8 & 21.5 \\
\hline Slovakia & 50.1 & 5.6 & 59.2 & 4.3 & 36.6 & 26.0 & 22.3 \\
\hline Finland & 117.0 & 0.1 & 63.7 & 3.0 & 33.3 & 20.0 & 26.4 \\
\hline Sweden & 127.5 & -0.4 & 70.2 & 1.8 & 28.0 & 18.1 & 26.1 \\
\hline United Kingdom & 118.9 & -0.4 & 74.9 & 0.8 & 24.2 & 16.9 & 22.5 \\
\hline Croatia & 49.6 & 3.3 & 65.0 & 6.9 & 28.1 & 23.8 & 18.4 \\
\hline
\end{tabular}

Source: Eurostat database (downloaded in 2012).

*ISCED - International Standard Classification of Education (ISCED) of the UNESCO. 
Table 3. Initial level of GDP, average annual growth rate and structural features of economic development, Croatian counties*

\begin{tabular}{|c|c|c|c|c|c|c|c|}
\hline $\begin{array}{l}\text { County } \\
\text { of Croatia }\end{array}$ & $\begin{array}{c}\text { GDP, p.c. } \\
\text { EU27=100, } \\
2000 .\end{array}$ & $\begin{array}{c}\text { Average } \\
\text { annual } \\
\text { growth of } \\
\text { GDP, p.c., } \\
\text { 2000-2008 }\end{array}$ & $\begin{array}{l}\text { Services, as } \\
\% \text { of GVA }\end{array}$ & $\begin{array}{l}\text { Agriculture, } \\
\text { as \% of GVA }\end{array}$ & $\begin{array}{l}\text { Industry, as } \\
\% \text { of GVA }\end{array}$ & $\begin{array}{l}\text { Investment, } \\
\text { as \% of GDP }\end{array}$ & $\begin{array}{c}\text { Pupils and } \\
\text { Students in all } \\
\text { levels of education } \\
\left.\text { (ISCED }{ }^{* *} 0-6\right) \text { - as } \\
\% \text { of total popula- } \\
\text { tion at regional } \\
\text { level }\end{array}$ \\
\hline County of Zagreb & 36.0 & 3.7 & 66.9 & 6.3 & 26.8 & 16.6 & 20.3 \\
\hline Krapina-Zagorje & 40.0 & 1.1 & 51.3 & 8.3 & 40.4 & 22.3 & 20.3 \\
\hline Sisak-Moslavina & 43.7 & 1.7 & 46.6 & 9.6 & 43.8 & 17.8 & 16.5 \\
\hline Karlovac & 43.6 & 1.7 & 57.8 & 7.5 & 34.7 & 20.9 & 20.3 \\
\hline Varaždin & 46.8 & 2.2 & 52.8 & 11.2 & 36.0 & 20.1 & 20.3 \\
\hline $\begin{array}{l}\text { Koprivnica- } \\
\text { Križevci }\end{array}$ & 50.9 & 1.6 & 41.7 & 20.4 & 37.9 & 16.1 & 20.3 \\
\hline Bjelovar-Bilogora & 39.3 & 2.8 & 51.0 & 25.5 & 23.5 & 12.6 & 16.5 \\
\hline $\begin{array}{l}\text { Primorje-Gorski } \\
\text { kotar }\end{array}$ & 58.4 & 3.2 & 67.0 & 1.5 & 31.5 & 25.9 & 17.8 \\
\hline Lika-Senj & 41.6 & 5.5 & 56.3 & 11.0 & 32.7 & 76.7 & 17.8 \\
\hline $\begin{array}{l}\text { Virovitica- } \\
\text { Podravina }\end{array}$ & 40.2 & 1.2 & 46.3 & 27.1 & 26.6 & 11.2 & 16.5 \\
\hline Požega-Slavonia & 37.3 & 0.9 & 53.3 & 20.2 & 26.5 & 16.7 & 16.5 \\
\hline $\begin{array}{l}\text { Slavonski } \\
\text { Brod-Posavina }\end{array}$ & 31.4 & 1.9 & 54.6 & 15.7 & 29.7 & 16.7 & 16.5 \\
\hline Zadar & 38.8 & 4.2 & 71.4 & 6.4 & 22.2 & 28.5 & 17.8 \\
\hline Osijek-Baranja & 39.2 & 3.7 & 55.8 & 15.6 & 28.6 & 20.9 & 16.5 \\
\hline Šibenik-Knin & 34.1 & 4.5 & 71.9 & 4.3 & 23.8 & 23.5 & 17.8 \\
\hline Vukovar-Sirmium & 30.5 & 3.2 & 53.9 & 21.7 & 24.4 & 24.9 & 16.5 \\
\hline Split-Dalmatia & 38.6 & 3.3 & 69.4 & 2.7 & 27.9 & 26.5 & 17.8 \\
\hline Istria & 66.7 & 2.0 & 64.0 & 3.2 & 32.8 & 23.7 & 17.8 \\
\hline $\begin{array}{l}\text { Dubrovnik- } \\
\text { Neretva }\end{array}$ & 44.4 & 4.5 & 72.7 & 5.1 & 22.2 & 21.3 & 17.8 \\
\hline Međimurje & 41.9 & 3.0 & 45.1 & 13.0 & 41.9 & 16.2 & 20.3 \\
\hline City of Zagreb & 83.5 & 3.4 & 76.6 & 0.2 & 23.2 & 26.9 & 20.3 \\
\hline
\end{tabular}

Source: Eurostat database (downloaded in 2012).

*Data on pupils and students are available only for NUTS II region.

**ISCED - International Standard Classification of Education (ISCED) of the UNESCO.

Table 3 presents the main economic indicators and structural features of the economic development of Croatian counties. The GDP per capita in base year (2000) of all Croatian counties is below the EU 27 average and significant dispersion of development can be noticed.

Table 4 shows indicators of regional differences in new member states and Croatia. For each of the selected countries the indicators for the most and the least developed county (minimum, maximum) are given, where EU27=100. The highest ratio between the minimum and maximum (ratio $\mathrm{max} / \mathrm{min}$ ) developed region in 2008 is registered in Romania (3.9). On the other hand, Slovenia (1.4) and Croatia (1.7) had the lowest $\mathrm{max} / \mathrm{min}$ ratio. The highest difference of the $\mathrm{max} / \mathrm{min}$ ratio for the period $2000-2008$ was recorded in Bulgaria and Romania (0.8), indicating a significant growth in economic inequalities.
The data on standard deviation show that regional differences between counties were increasing in all countries for the period 2000-2008. The difference between standard deviation in 2008 and the base year were the highest in Slovakia (20.6), Romania (14.5) and Bulgaria (11.1). By contrast, Poland (2.5) recorded relatively slow growth of inequalities during this period.

Apart from Poland and Slovenia, Croatia recorded the smallest change in $\mathrm{max} / \mathrm{min}$ ratio and standard deviation for the period 2000-2008, indicating a very slow process of within-country convergence despite different general public perceptions. A list of all regions at the NUTSII level can be found in the Appendix, Table A. 
Table 4. Indicators of regional differences in economic development, NMS and Croatia

\begin{tabular}{|c|c|c|c|c|c|c|c|c|c|c|}
\hline & 2000 & 2001 & 2002 & 2003 & 2004 & 2005 & 2006 & 2007 & 2008 & $\begin{array}{l}\text { Difference } \\
2008-2000\end{array}$ \\
\hline \multicolumn{11}{|l|}{ Bulgaria } \\
\hline Minimum & 21.5 & 22.8 & 23.5 & 25.6 & 26.6 & 27.5 & 26.2 & 26.7 & 28.2 & 6.6 \\
\hline Maximum & 37.5 & 41.2 & 45.5 & 48.6 & 50.9 & 54.3 & 59.8 & 66.4 & 72.4 & 34.9 \\
\hline Ratio max/min & 1.7 & 1.8 & 1.9 & 1.9 & 1.9 & 2.0 & 2.3 & 2.5 & 2.6 & 0.8 \\
\hline Standard deviation & 5.7 & 6.5 & 7.8 & 8.6 & 9.4 & 10.3 & 12.6 & 15.1 & 16.8 & 11.1 \\
\hline \multicolumn{11}{|l|}{ Czech R. } \\
\hline Minimum & 53.4 & 54.6 & 54.0 & 56.7 & 59.4 & 59.2 & 59.7 & 61.4 & 62.2 & 8.9 \\
\hline Maximum & 136.5 & 145.0 & 147.4 & 153.7 & 154.2 & 158.4 & 161.6 & 171.1 & 172.6 & 36.1 \\
\hline Ratio max/min & 2.6 & 2.7 & 2.7 & 2.7 & 2.6 & 2.7 & 2.7 & 2.8 & 2.8 & 0.2 \\
\hline Standard deviation & 27.5 & 30.2 & 31.1 & 32.4 & 31.9 & 33.2 & 34.2 & 36.9 & 37.2 & 9.7 \\
\hline \multicolumn{11}{|l|}{ Hungary } \\
\hline Minimum & 36.0 & 37.9 & 39.2 & 40.6 & 41.4 & 40.0 & 39.7 & 38.9 & 39.7 & 3.7 \\
\hline Maximum & 85.6 & 93.5 & 100.7 & 100.1 & 101.4 & 103.2 & 105.1 & 103.6 & 107.0 & 21.4 \\
\hline Ratio $\mathrm{max} / \mathrm{min}$ & 2.4 & 2.5 & 2.6 & 2.5 & 2.4 & 2.6 & 2.6 & 2.7 & 2.7 & 0.3 \\
\hline Standard deviation & 18.1 & 19.8 & 21.9 & 21.5 & 21.8 & 22.6 & 23.7 & 23.3 & 24.1 & 5.9 \\
\hline \multicolumn{11}{|l|}{ Poland } \\
\hline Minimum & 33.6 & 33.4 & 33.8 & 34.5 & 35.0 & 35.0 & 35.0 & 36.8 & 38.8 & 5.2 \\
\hline Maximum & 72.8 & 74.3 & 74.5 & 75.9 & 77.0 & 81.3 & 82.8 & 87.2 & 88.7 & 15.9 \\
\hline Ratio $\max / \mathrm{min}$ & 2.2 & 2.2 & 2.2 & 2.2 & 2.2 & 2.3 & 2.4 & 2.4 & 2.3 & 0.1 \\
\hline Standard deviation & 9.6 & 10.0 & 9.9 & 10.1 & 10.3 & 11.2 & 11.6 & 12.2 & 12.1 & 2.5 \\
\hline \multicolumn{11}{|l|}{ Romania } \\
\hline Minimum & 18.1 & 20.4 & 21.3 & 22.5 & 23.5 & 23.3 & 24.7 & 26.6 & 28.8 & 10.7 \\
\hline Maximum & 56.4 & 57.3 & 59.1 & 62.6 & 68.1 & 76.8 & 83.7 & 91.9 & 113.1 & 56.7 \\
\hline Ratio $\mathrm{max} / \mathrm{min}$ & 3.1 & 2.8 & 2.8 & 2.8 & 2.9 & 3.3 & 3.4 & 3.5 & 3.9 & 0.8 \\
\hline Standard deviation & 12.1 & 11.7 & 12.1 & 12.8 & 13.9 & 16.9 & 18.5 & 20.6 & 26.6 & 14.5 \\
\hline \multicolumn{11}{|l|}{ Slovenia } \\
\hline Minimum & 67.2 & 66.5 & 68.7 & 68.7 & 71.5 & 72.6 & 72.3 & 73.0 & 75.6 & 8.3 \\
\hline Maximum & 94.4 & 95.0 & 98.1 & 100.6 & 103.6 & 104.9 & 105.4 & 106.6 & 108.9 & 14.4 \\
\hline Ratio $\mathrm{max} / \mathrm{min}$ & 1.4 & 1.4 & 1.4 & 1.5 & 1.4 & 1.4 & 1.5 & 1.5 & 1.4 & 0.0 \\
\hline Standard deviation & 19.2 & 20.1 & 20.8 & 22.5 & 22.7 & 22.9 & 23.5 & 23.8 & 23.5 & 4.3 \\
\hline \multicolumn{11}{|l|}{ Slovakia } \\
\hline Minimum & 37.7 & 40.1 & 41.0 & 41.3 & 42.0 & 43.0 & 43.8 & 46.4 & 50.8 & 13.2 \\
\hline Maximum & 108.7 & 115.4 & 122.2 & 124.6 & 128.8 & 146.5 & 147.7 & 160.9 & 166.9 & 58.1 \\
\hline Ratio $\max / \min$ & 2.9 & 2.9 & 3.0 & 3.0 & 3.1 & 3.4 & 3.4 & 3.5 & 3.3 & 0.4 \\
\hline Standard deviation & 33.5 & 35.8 & 38.6 & 39.4 & 40.9 & 49.2 & 48.6 & 53.3 & 54.1 & 20.6 \\
\hline \multicolumn{11}{|l|}{ Croatia } \\
\hline Minimum & 37.8 & 38.6 & 39.9 & 39.7 & 40.1 & 40.0 & 40.8 & 42.1 & 45.8 & 7.9 \\
\hline Maximum & 60.9 & 62.5 & 65.2 & 68.0 & 69.2 & 71.7 & 73.0 & 76.1 & 78.2 & 17.3 \\
\hline Ratio $\mathrm{max} / \mathrm{min}$ & 1.6 & 1.6 & 1.6 & 1.7 & 1.7 & 1.8 & 1.8 & 1.8 & 1.7 & 0.1 \\
\hline Standard deviation & 11.5 & 12.0 & 12.8 & 14.1 & 14.5 & 15.9 & 16.1 & 17.0 & 16.2 & 4.7 \\
\hline
\end{tabular}

Source: Eurostat database (downloaded in 2012). 


\section{MODEL FOR TESTING CONVERGENCE HYPOTHESIS IN THE EUROPEAN UNION, NEW MEMBER STATES AND CROATIA}

In this chapter various models for testing hypotheses on convergence are presented. A concept of convergence is derived from the neoclassical model according to which the rate of growth of an economy is inversely correlated with its initial level of development (absolute $\beta$-convergence). As a tool for testing a hypothesis on absolute $\beta$-convergence we used the following model:

$$
\ln \frac{Y i 2008}{Y i 2000}=\alpha+\beta \ln Y i 2000+\varepsilon i
$$

where:

Yi2008 - GDP per capita in EURO PPS in region $i$ in 2008, Yi2000 - GDP per capita in EURO PPS in region $i$ in 2000 (initial period),

$\alpha$ - constant to be estimated in model,

$\beta$ - parameter to be estimated in model,

$\mathrm{i}$ - denotes regions covered in the model (in the model covering the EU, $\mathrm{i}$ goes from 1 to 28 , in the NMS model i goes from 1 to 59 , while in the case of Croatia i goes from 1 to 21)

$\varepsilon$ - error term.

The main aim of this research is to test for signs of regional convergence in Croatia and to compare the results of the same model applied to EU member states and the EU NUTS II regions. However, the choice of the applied method primarily related to the availability of data. In the Croatian case, some socioeconomic variables are not available on an annual basis and harmonization according to Eurostat concepts has been completed only for certain years. Therefore, a simple cross-section OLS model is applied instead of a panel data model which could provide a better description of the convergence pattern. Selection of the initial year is also based on a data availability issue, as regional GDP data for Croatia was published in the year 2000 for the first time. A data set for longer periods, covering the pre-transition years and the first years of the transition process would have been more convenient for detailed research on regional growth patterns and identification of the role of the most significant socioeconomic variables, but unfortunately the data is not yet available in Croatia.

Recent literature suggests that spatial econometric techniques which are able to capture the influence of neighbouring regions on growth are more appropriate to determine the speed and intensity of the convergence process, in comparison to the traditional $\beta$-convergence approach. In this research, instead of a spatial econometric model a more traditional approach is applied primarily because of the lack of comparable data.

Croatian counties are extremely different regarding their size, and due to geographical shape there is significant diversity in a number of neighbouring counties. In addition, the majority of Croatian counties have an international border with Bosnia and Herzegovina or Serbia which have no comparable NUTS II regions. The study of spatial dependence and common exogenous factors are therefore left for further research.

In order to determine whether there is evidence of $a b-$ solute $\beta$-convergence, three equations are estimated, each comprising a different unit sample. In the first equation, the model is tested on the national level for a group of EU countries including Croatia which joined the EU in 2013. The second equation comprises the NUTS 2 regions of new member states (NMS) and Croatia, while the third equation is comprised of Croatian counties (NUTS III level). As can be seen from Table 5, strong evidence for absolute $\beta$-convergence can be found on the national level for EU countries. The estimated parameter for $\beta$-convergence is significant and has an expected sign. Some additional diagnostic tests are also presented in the tables. However, one should bear in mind that some of the estimated models have a small size, which could influence their reliability.

Two additional indicators for convergence speed are presented in the table. Both are derived from the estimate of parameter $\beta$ and could be found in various papers on convergence. The speed of convergence measures how fast economies converge towards the steady state and can be calculated from the following formula:

$$
\mathrm{s}=-\ln (1+\beta) / \mathrm{T}
$$

in which T stands for the number of periods for which we have data for per capita GDP growth rates (as a period from 2000 to 2008 is analysed, $T=8$ ).

The half-life period is defined as the time necessary for the economies to cover half of the initial lag from their steady states and can be calculated from the following formula:

$$
\tau=-\ln (2) / \ln (1+\beta / \mathrm{T}) .
$$

As can be seen from Table 5, the convergence process on the national economy level is relatively strong in the EU, and despite significant initial differences in development we can expect a strong convergence process as in the period under analysis half of the initial lag will be covered in less than 20 years. Of course, the recent economic recession would probably change the conclusions to an extent based on data for 2000-2008 since the issues of vulnerability of certain regions in period of crises have not been accounted for.

The econometric properties of the convergence equation comprising new member states of the NUTS 2 regions are not as good in comparison to the equation relating to national economies, although the parameter for $\beta$-convergence is still highly significant. The speed of convergence at the regional level is approximately half that at the national level. On the other hand, no evidence on regional convergence (on the county level) can be found in Croatia. The estimated parameters are absolutely insignificant and the estimated equation has a very low ability to explain regional development differences in Croatia. 
Table 5. Results for testing absolute $\beta$-convergence hypothesis

\begin{tabular}{|c|c|c|c|}
\hline & EU+Croatia & NMS NUTS 2 regions & Croatia \\
\hline & \multicolumn{3}{|c|}{$\ln \frac{Y i 2008}{Y i 2000}=\alpha+\beta \ln Y i 2000+\Upsilon j X j i+\varepsilon i$} \\
\hline Constant $(a)$ & $\begin{array}{l}3.3377^{* * *} \\
(9.2430)\end{array}$ & $\begin{array}{l}0.873^{* * *} \\
(-4.462)\end{array}$ & $\begin{array}{l}0.271 \\
(-0.843)\end{array}$ \\
\hline Initial level of GDP $(\beta)$ & $\begin{array}{c}-0.3058^{* * *} \\
(-6.410556)\end{array}$ & $\begin{array}{l}-0.166^{* *} \\
(-3.2233)\end{array}$ & $\begin{array}{l}-0.016 \\
(-0.189)\end{array}$ \\
\hline $\mathrm{R} 2$ & 0.756 & 0.154 & 0.002 \\
\hline Prob (F-stat) & 0.0000 & 0.0021 & 0.8520 \\
\hline \multicolumn{4}{|l|}{$\begin{array}{l}\text { Heteroskedasticity Test: } \\
\text { Breusch-Pagan-Godfrey }\end{array}$} \\
\hline F-statistic & 2.416 & 0.035 & 0.77 \\
\hline Obs*R-squared & 2.381 & 0.036 & 0.82 \\
\hline Number of units & 28 & 59 & 21 \\
\hline Speed of the convergence & 0.0456 & 0.0227 & 0.0020 \\
\hline Half-life period & 17.8 & 33.0 & 346.2 \\
\hline
\end{tabular}

t-statistics are in parentheses under the estimated coefficients.

Significance levels: ${ }^{* *} p<0.001 .{ }^{* *} p<0.01$ and ${ }^{*} p<0.1$.

Source: authors' calculations (eviews software is used) based on data from Eurostat (downloaded in 2012).

Tables 6 and 7 present results for testing the conditional $\beta$-convergence hypothesis. According to that hypothesis if other factors which determine economic growth differ among economies, then each particular economy will approach its own but unique equilibrium. The evidence should suggest the existence of conditional convergence if the negative relationship between initial per capita incomes and their growth rates holds only after the possibility of the above-mentioned structural characteristics has been controlled for. According to available data, as control variables in the paper we used data on regional structure of gross value added (GVA) share of fixed capital formation (investment) in GDP and share of pupils and students in overall population (education).

$$
\ln \frac{Y i 2008}{Y i 2000}=\alpha+\beta \ln Y i 2000+Y j X j i+\varepsilon i
$$

In addition to the symbols defined above, $\mathrm{Xj}$ stands for additional development factors (education, investment, share of agriculture in GVA, share of industry in GVA and share of services in GVA) and are parameters to be estimated for each of the relevant factors.

The results for the beta-convergence parameter after investment and education are included as control variables and presented in Table 6 . As can be seen from the equation comprising EU countries, education as a control variable is not a significant factor in explaining differences in economic development, while share of investment has a limited impact on speed of the convergence. Although fixed capital and human capital are important factors in all growth models, other benefits of EU accession (free movement of goods and capital, availability of structural funds) dominated over traditional factors in the period under analysis. 
Table 6. Results for testing conditional $\beta$-convergence hypothesis (control variables for investment and education)

\begin{tabular}{|c|c|c|c|c|c|c|c|c|c|}
\hline & \multicolumn{3}{|c|}{ EU28 } & \multicolumn{3}{|c|}{ NMS NUTS 2 regions + Croatia } & \multicolumn{3}{|c|}{ Croatia } \\
\hline & \multicolumn{9}{|c|}{$\ln \frac{Y i 2008}{Y i 2000}=\alpha+\beta \ln Y i 2000+\Upsilon j X j i+\varepsilon i$} \\
\hline Constant (a) & $\begin{array}{l}2.65^{* * *} \\
(5.059)\end{array}$ & $\begin{array}{c}3.349^{* * *} \\
(8.756)\end{array}$ & $\begin{array}{c}2.664^{* * *} \\
(5.386)\end{array}$ & $\begin{array}{c}0.548^{* *} \\
(2.901)\end{array}$ & $\begin{array}{c}0.721^{* * *} \\
(3.684)\end{array}$ & $\begin{array}{c}0.696^{* * *} \\
(3.630)\end{array}$ & $\begin{array}{l}0.256 \\
(0.790)\end{array}$ & $\begin{array}{c}0.286 \\
(0.817)\end{array}$ & $\begin{array}{c}0.296 \\
(0.844)\end{array}$ \\
\hline Initial level of GDP $(\beta)$ & $\begin{array}{l}-0.266^{* * *} \\
(-6.230)\end{array}$ & $\begin{array}{l}-0.305^{* * *} \\
(-7.778)\end{array}$ & $\begin{array}{l}-0.266^{* * *} \\
(-6.411)\end{array}$ & $\begin{array}{c}-0.267^{* * *} \\
(-5.133)\end{array}$ & $\begin{array}{c}-0.228^{* * *} \\
(2.598)\end{array}$ & $\begin{array}{l}-0.207^{* * *} \\
(-4.149)\end{array}$ & $\begin{array}{l}-0.0273 \\
(-0.309)\end{array}$ & $\begin{array}{l}-0.011 \\
(-0.120)\end{array}$ & $\begin{array}{l}-0.029 \\
(-0.367)\end{array}$ \\
\hline Education & $\begin{array}{c}0.001 \\
(0.098)\end{array}$ & $\begin{array}{l}-0.001 \\
(-0.106)\end{array}$ & & $\begin{array}{c}0.018^{* *} \\
(2.749)\end{array}$ & $\begin{array}{l}0.018^{*} \\
(2.598)\end{array}$ & & $\begin{array}{l}-0.0006 \\
(-0.049)\end{array}$ & $\begin{array}{l}-0.0017 \\
(-0.1262)\end{array}$ & \\
\hline Investment & $\begin{array}{l}0.013^{*} \\
(1.857)\end{array}$ & & $\begin{array}{l}0.013^{*} \\
(1.896)\end{array}$ & $\begin{array}{c}0.0146^{* *} \\
(3.195)\end{array}$ & & $\begin{array}{l}0.015^{* *} \\
(3.068)\end{array}$ & $\begin{array}{c}-0.0030^{*} \\
(2.016)\end{array}$ & & $\begin{array}{l}0.0029 * \\
(2.078)\end{array}$ \\
\hline $\mathrm{R} 2$ & 0.755 & 0.755 & 0.720 & 0.363 & 0.245 & 0.276 & 0.195 & 0.002 & 0.195 \\
\hline Prob (F-stat) & 0.000 & 0.000 & 0.000 & 0.000 & 0.000 & 0.000 & 0.285 & 0.975 & 0.142 \\
\hline \multicolumn{10}{|l|}{$\begin{array}{l}\text { Heteroskedasticity Test: } \\
\text { Breusch-Pagan-Godfrey }\end{array}$} \\
\hline F-statistics & 1.566 & 2.24 & 1.336 & 1.26 & 3.32 & 0.44 & 0.298 & 0.48 & 0.44 \\
\hline Obs*R & 4.58 & 4.26 & 5.089 & 3.80 & 5.82 & 0.95 & 1.05 & 1.06 & 0.98 \\
\hline Number of units & 28 & 28 & 28 & 59 & 59 & 59 & 21 & 21 & 21 \\
\hline $\begin{array}{l}\text { Speed of the } \\
\text { convergence }\end{array}$ & 0.0387 & 0.0455 & 0.0386 & 0.0388 & 0.0232 & 0.0290 & 0.0035 & 0.0014 & 0.0037 \\
\hline Half-life period & 20.5 & 17.8 & 20.5 & 20.4 & 32.3 & 26.4 & 202.6 .6 & 484.3 & 190.6 \\
\hline
\end{tabular}

t-statistics are in parentheses under the estimated coefficients.

Significance levels: ${ }^{* *} p<0.001 .{ }^{* *} p<0.01$ and ${ }^{*} p<0.1$.

Source: authors' calculations (eviews software is used) based on data from Eurostat (downloaded in 2012).

On the other hand, education and investment activity have significance in explaining development differences in the NUTS 2 regions of new member states. Speed of convergence after controlling for those variables is approximately the same as in the analyses on the national economy level, meaning that NMS regions with a higher proportion of educated population and higher attractiveness for investors benefited more from EU accession. The model for Croatia has low explanatory power for development differences even after accounting for education and investment as additional variables, although the investment parameter is significant and is expectedly positive. On average, Croatian counties with stronger investment activity recorded higher economic growth.

The results for testing the impact of structural features on the convergence process are presented in Table 7. In the model for EU countries, economic structure has low impact on growth and the inclusion of control variables do not significantly change conclusions on the convergence process. The same holds for the NUTS 2 regions of new member states. On the other hand, the economic structure of Croatian regions is significant in explaining growth differences. Croatian counties specialized in the service sector recorded higher growth rates, while regions with a higher share of agriculture recorded slower growth. Counties with a higher share of industry also recorded lower growth rates, which is probably a consequence of the slow process of industry sector restructuring in Croatia. 
Table 7. Results for testing conditional $\beta$-convergence hypothesis (economic structure used as control variables)

\begin{tabular}{|c|c|c|c|c|c|c|c|c|c|}
\hline & \multicolumn{3}{|c|}{ EU+Croatia } & \multicolumn{3}{|c|}{ NMS NUTS 2 regions+Croatia } & \multicolumn{3}{|c|}{ Croatia } \\
\hline & \multicolumn{9}{|c|}{$\ln \frac{Y i 2008}{Y i 2000}=\alpha+\beta \ln Y i 2000+\gamma j X j i+\varepsilon i$} \\
\hline Constant (a) & $\begin{array}{c}2.840 * * * \\
(3.826)\end{array}$ & $\begin{array}{c}3.330^{* * * *} \\
(7.426)\end{array}$ & $\begin{array}{c}3.335^{* * *} \\
(9.059)\end{array}$ & $\begin{array}{c}1.333^{* * *} \\
(3.546)\end{array}$ & $\begin{array}{l}0.939 * * * \\
(4.074)\end{array}$ & $\begin{array}{c}0.818^{* * *} \\
(4.037)\end{array}$ & $\begin{array}{l}0.706^{* *} \\
(2.106)\end{array}$ & $\begin{array}{c}0.380 \\
(1.331)\end{array}$ & $\begin{array}{c}0.176 \\
(0.748)\end{array}$ \\
\hline Initial level of GDP $(\beta)$ & $\begin{array}{l}-0.259^{* *} \\
(-3.529)\end{array}$ & $\begin{array}{c}-0.305^{* * *} \\
(-7.465)\end{array}$ & $\begin{array}{l}-0.300 * * * \\
(-6.218)\end{array}$ & $\begin{array}{l}-0.268^{* *} \\
(-3.057)\end{array}$ & $\begin{array}{l}-0.170^{* *} \\
(-3.246)\end{array}$ & $\begin{array}{l}-0.200^{* *} \\
(-3.299)\end{array}$ & $\begin{array}{l}-0.113 \\
(-1.325)\end{array}$ & $\begin{array}{c}0.011 \\
(0.147)\end{array}$ & $\begin{array}{l}-0.089 \\
(-1.372)\end{array}$ \\
\hline Agriculture & $\begin{array}{c}0.012 \\
(0.770)\end{array}$ & & & $\begin{array}{l}-0.011 \\
(-1.428) \\
\end{array}$ & & & $\begin{array}{l}-0.006^{* *} \\
(-2.472)\end{array}$ & & \\
\hline Industry & & $\begin{array}{c}0.000 \\
(0.028)\end{array}$ & & & $\begin{array}{l}-0.002 \\
(-0.550)\end{array}$ & & & $\begin{array}{l}-0.007^{*} \\
(-2.579)\end{array}$ & \\
\hline Services & & & $\begin{array}{l}-0.001 \\
(-0.213)\end{array}$ & & & $\begin{array}{c}0.003 \\
(1.055)\end{array}$ & & & $\begin{array}{c}0.006^{* * *} \\
(4.220)\end{array}$ \\
\hline $\mathrm{R} 2$ & 0.726 & 0.720 & 0.720 & 0.184 & 0.159 & 0.276 & 0.255 & 0.271 & 0.498 \\
\hline Prob (F-stat) & 0.000 & 0.000 & 0.000 & 0.003 & 0.008 & 0.000 & 0.071 & 0.058 & 0.002 \\
\hline \multicolumn{10}{|l|}{$\begin{array}{l}\text { Heteroskedasticity Test: } \\
\text { Breusch-Pagan-Godfrey }\end{array}$} \\
\hline F-statistics & 3.078 & 3.01 & 2.096 & 0.73 & 0.82 & 1.31 & 0.27 & 0.59 & 1.35 \\
\hline Obs*R & 5.53 & 5.44 & 4.02 & 1.51 & 1.68 & 2.63 & 0.67 & 1.28 & 2.73 \\
\hline Number of units & 28 & 28 & 28 & 59 & 59 & 59 & 21 & 21 & 21 \\
\hline $\begin{array}{l}\text { Speed of the } \\
\text { convergence }\end{array}$ & 0.037 & 0.046 & 0.045 & 0.039 & 0.023 & 0.028 & 0.015 & -0.001 & 0.012 \\
\hline Half-life period & 21.1 & 17.8 & 18.1 & 20.4 & 32.3 & 27.4 & 48.7 & -499.2 & 62.3 \\
\hline
\end{tabular}

$\mathrm{t}$-statistics are in parentheses under the estimated coefficients.

Significance levels: ${ }^{* *} p<0.001 .{ }^{* *} p<0.01$ and ${ }^{*} p<0.1$.

Source: authors' calculations (eviews software is used) based on data from Eurostat (downloaded in 2012).

\section{CONCLUSION}

Based on evidence of significant disparities in regional development, the EU introduced a set of policy measures to promote the integration and convergence of less developed areas of the Member States. Consequently, according to GDP per capita data at the national level, overall disparities in the EU have recently diminished. On the other hand, an increasing dispersion in economic development can be found among the regions of individual new member states.

According to the absolute convergence hypothesis, the per capita incomes of countries or regions converge with one another in the long-term regardless of other initial conditions. In conditional convergence models, there is a negative relation between initial development and growth, but the impact of other factors could produce a different steady-state for different regions. Most recent empirical researches confirm the convergence hypothesis at the overall EU level, but in most cases regional convergence within individual countries could not be found. Capital cities and major urban areas, which are generally the most developed areas, recorded higher growth of income, while less developed areas are lagging behind.

According to our model, absolute $\beta$-convergence can be found on the national level for EU countries, which is in line with previous studies. Convergence also can be found for NMS regions, but convergence speed on the regional level is lower in comparison to the national level and the estimated $\beta$-convergence parameter is less significant. No evidence on regional convergence (on the county level) can be found in Croatia, and disparities have been highly persistent throughout the period of 2000-2008. More precisely, aside from Latvia and Portugal, Croatia recorded the smallest change in regional dispersion between 2000-2008 (1.5) when compared to NMS.

At the national level, education as an additional variable 
is not significant in explaining differences in economic development, as well as variables reflecting economic structure, while share of investment has limited impact on the speed of convergence. Obviously, in the first years of EU membership the benefits from free movement of goods, significant capital inflow and the availability of structural funds dominated over traditional factors like availability of human and fixed capital.

Contrary to previous conclusions on the national level, education and share of investment in GDP are significant in explaining differences in development for the NUTS 2 regions of new member states. This means that NMS regions with a more highly educated population and higher attractiveness for investors benefited more from EU accession in comparison to the regions with less educated populations and lower investment levels. In order to reduce the development gap, national governments should introduce various programs for improving education and the promotion of investment in less developed regions. Models for testing the conditional convergence for Croatia have low explicatory power for development differences and we can conclude that in the case of Croatia, a regional convergence process is absent. The most developed counties in Croatia at the same time have a higher proportion of GVA in industries with high growth potential. As such, the availability of structural funds should be primarily used for improvement in overall regional investment attractiveness, which could promote the economic restructuring of less developed regions.

\section{REFERENCES}

Arbia, G. and Piras, G. 2005. Convergence in per-capita GDP across European regions using panel data models extended to spatial autocorrelation effects. Working paper no. 51 May 2005. Institute for Studies and Economic Analyses. Roma.

Arbia, G., Basile, R. and Piras, G. 2005. Using Spatial Panel Data in Modelling Regional Growth and Convergence. - Working Paper. No 55. Regional Economic Growth Application Laboratory. University of Illinois at Urbana-Champaign.

Barro, R. and Sala-i-Martin, X. 1992. Convergence. Journal of Political Economy. 100(2): 223-251.

Baumol, W. J. 1986. Productivity growth, convergence and welfare: What the longrun data show. The American Economic Review 76(5): 1072-1085.

Baumont, C., Ertur, C. and Le Gallo, J. 2002. The European Regional Convergence Process. 1980-1995: Do Spatial Regimes and Spatial Dependence Matter? University of Burgundy. http:// cournot2.u-strasbg.fr/users/j-econometres02/papers/SR1101. pdf

Botric, V. 2003. Regional differences in unemployment: the case of Croatia. ERSA conference papers ersa03p25. European Regional Science Association

Cappelen, A. 2001. Convergence, Divergence and the Kuznetscurve. Paper prepared as part of the Project: "Technology, Economic Integration and Social Cohesion", sponsored by the European Commission under the TSER Programme.
Checherita, C., Nickel, C and Rother, P. 2009. The role of fiscal transfers for regional economic convergence in Europe. Working Paper Series. 1029. European Central Bank.

Drezgić, S. 2011. Public investments and regional income convergence: empirical analysis of Croatian regions. Social research. 3 (24): 43-55.

Durlauf, S. N. 2001. Manifesto for a growth econometrics. Journal of Econometrics. 100: 65-69.

Fischer, M. M. and Stirböck, C. 2004. Regional Income Convergence in the Enlarged Europe 1995-2000: A Spatial Econometric Perspective. ZEW Discussion Paper. 04: 42p.

Förster, M. and Smeeding, T. 2005. Regional Poverty and Income Inequality in Central and Eastern Europe: Evidence from the Luxembourg Income Study. in Kanbur R. Venables AJ (eds). Spatial Inequality and Development. Oxford University Press.

López-Bazo, E., Valcarce, E. V. , Corral, A. J. M. and Caralt, J. S. 1997. Regional economic dynamics and convergence in the European Union. http://www.ere.ub.es/dtreball/E9712.rdf/ at_download/file $62 \mathrm{p}$.

Maleković, S., Puljiz, J. and Tišma, S. 2011 New Opportunities for Regional and Local Actors in Croatia in Supporting SocioEconomic Development Source: Southeastern Europe. 35(2): 168-190.

Mankiw, N.G. 1995. The Growth of Nations. Brookings Papers on Economic Activity. 275-326.

Martin, R. 2001. EMU versus the regions? Regional convergence and divergence in Euroland. Journal of Economic Geography. 1:51-80.

Melchior, A. 2009. Regional Inequality and Convergence in Europe 1995-2005. Norwegian Institute of International Affairs April 23. 2009 CASE Network Studies and Analyses No. 374.

Neven, D.J. and Gouyette, C. 1994. Regional convergence in the European Community, CEPR Discussion Paper Series 914.

North, D. 1990. Institutions, Institutional Change and Economic Performance. Cambridge: Cambridge University Press.

Paas, T. and Schlitte, P. 2007. Regional Income Inequality and Convergence Processes in the EU25. HWWI_Research_Paper: 1-11.

Quah, D. T. 1993. Galton's Fallacy and the Convergence Hypothesis. Scandinavian Journal of Economics. 95: 427-443.

Rey, S.J. and Montouri, B.D. 1998. U.S. Regional Income Convergence: A Spatial Econometric Perspective. San Diego State University. Department of Geography. San Diego.

Sala-i-Martin, X. 1996. Regional Cohesion: Evidence and Theories of Regional Growth and Convergence. European Economic Review. 40(6): 1325-1352.

Tsionas. E. G. 2000. Regional growth and convergence: evidence from the United States. - Regional Studies. 34: 231-238. 


\section{APPENDIX}

Table A: Initial level of GDP, average annual growth rate and structural features of economic development, NUTS II regions of new member states and Croatia

\begin{tabular}{|c|c|c|c|c|c|c|c|}
\hline NUTS II region & $\begin{array}{l}\text { GDP, p.c. } \\
\text { EU27=100, } \\
2000 .\end{array}$ & $\begin{array}{l}\text { Average an- } \\
\text { nual growth } \\
\text { of GDP, p.c., } \\
2000-2008\end{array}$ & $\begin{array}{l}\text { Services, } \\
\text { as \% of } \\
\text { GVA }\end{array}$ & $\begin{array}{l}\text { Agriculture, } \\
\text { as \% of GVA }\end{array}$ & $\begin{array}{l}\text { Industry, } \\
\text { as \% of } \\
\text { GVA }\end{array}$ & $\begin{array}{l}\text { Investment, } \\
\text { as \% of GDP }\end{array}$ & $\begin{array}{l}\text { Pupils and Students } \\
\text { in all levels of educa- } \\
\text { tion (ISCED 0-6) - as \% } \\
\text { of total population at } \\
\text { regional level }\end{array}$ \\
\hline Severozapaden & 25.6 & 1.3 & 52.9 & 17.6 & 29.5 & 0.0 & 14.4 \\
\hline Severen tsentralen & 23.5 & 3.1 & 55.5 & 16.1 & 28.4 & 0.0 & 18.2 \\
\hline Severoiztochen & 27.2 & 4.1 & 61.5 & 12.5 & 26.0 & 0.0 & 19.4 \\
\hline Yugoiztochen & 29.6 & 2.6 & 51.2 & 11.5 & 37.3 & 0.0 & 16.2 \\
\hline Yugozapaden & 37.5 & 8.6 & 70.4 & 3.6 & 26.1 & 0.0 & 19.4 \\
\hline Yuzhen tsentralen & 21.5 & 4.4 & 55.7 & 14.6 & 29.6 & 0.0 & 16.9 \\
\hline Praha & 136.5 & 3.0 & 81.6 & 0.2 & 18.2 & 29.7 & 28.7 \\
\hline Strední Cechy & 64.4 & 1.8 & 51.6 & 3.8 & 44.5 & 26.7 & 14.7 \\
\hline Jihozápad & 63.5 & 0.9 & 52.7 & 5.4 & 41.9 & 27.0 & 19.6 \\
\hline Severozápad & 56.1 & 1.3 & 50.7 & 2.2 & 47.1 & 25.7 & 18.5 \\
\hline Severovýchod & 61.5 & 0.6 & 51.3 & 4.2 & 44.6 & 22.9 & 19.3 \\
\hline Jihovýchod & 61.3 & 2.3 & 55.2 & 5.3 & 39.4 & 25.7 & 22.6 \\
\hline Strední Morava & 55.9 & 1.8 & 51.5 & 4.5 & 44.1 & 24.9 & 20.1 \\
\hline Moravskoslezsko & 53.4 & 3.4 & 50.5 & 2.2 & 47.3 & 24.1 & 21.5 \\
\hline Eesti & 45.1 & 5.3 & 67.5 & 3.8 & 28.7 & 30.6 & 22.9 \\
\hline Cyprus & 88.7 & 1.2 & 77.9 & 3.0 & 19.1 & 10.3 & 21.4 \\
\hline Estonia & 45.1 & 5.3 & 67.5 & 3.8 & 28.7 & 30.6 & 22.9 \\
\hline Latvia & 36.7 & 5.5 & 73.3 & 4.0 & 22.6 & 27.7 & 22.0 \\
\hline Lithuania & 39.3 & 5.7 & 63.5 & 4.9 & 31.6 & 22.4 & 24.5 \\
\hline Közép-Magyarország & 85.6 & 2.9 & 76.2 & 0.9 & 22.9 & 17.6 & 22.7 \\
\hline Közép-Dunántúl & 53.5 & 1.1 & 48.7 & 4.9 & 46.4 & 24.5 & 20.0 \\
\hline Nyugat-Dunántúl & 63.2 & 0.0 & 51.2 & 5.3 & 43.6 & 21.7 & 19.8 \\
\hline Dél-Dunántúl & 42.2 & 0.6 & 63.0 & 9.4 & 27.6 & 22.2 & 22.0 \\
\hline Észak-Magyarország & 36.0 & 1.3 & 56.3 & 5.3 & 38.5 & 23.1 & 22.0 \\
\hline Észak-Alföld & 36.1 & 1.4 & 60.4 & 9.2 & 30.4 & 23.1 & 23.3 \\
\hline Dél-Alföld & 41.1 & 0.6 & 60.4 & 11.8 & 27.8 & 20.3 & 21.4 \\
\hline Lódzkie & 43.4 & 2.4 & 62.6 & 6.1 & 31.4 & 18.9 & 23.0 \\
\hline Mazowieckie & 72.8 & 2.5 & 74.0 & 3.9 & 22.1 & 23.6 & 26.0 \\
\hline Malopolskie & 41.9 & 1.9 & 67.1 & 2.9 & 29.9 & 20.8 & 25.8 \\
\hline Slaskie & 51.9 & 2.0 & 59.9 & 1.3 & 38.8 & 16.9 & 21.5 \\
\hline Lubelskie & 33.7 & 1.9 & 67.6 & 7.8 & 24.5 & 16.5 & 23.9 \\
\hline Podkarpackie & 33.6 & 1.8 & 63.7 & 3.4 & 32.9 & 18.9 & 23.1 \\
\hline Swietokrzyskie & 37.4 & 2.4 & 62.3 & 6.6 & 31.1 & 17.4 & 22.9 \\
\hline Podlaskie & 36.3 & 1.6 & 65.3 & 10.5 & 24.3 & 19.0 & 23.6 \\
\hline Wielkopolskie & 51.3 & 1.7 & 59.9 & 7.4 & 32.7 & 20.8 & 25.3 \\
\hline Zachodniopomorskie & 49.1 & 0.5 & 70.5 & 4.7 & 24.9 & 18.1 & 22.8 \\
\hline Lubuskie & 43.4 & 1.4 & 63.8 & 4.5 & 31.6 & 19.5 & 21.5 \\
\hline Dolnoslaskie & 50.1 & 2.4 & 62.4 & 2.8 & 34.8 & 21.2 & 23.1 \\
\hline Opolskie & 40.7 & 2.1 & 59.8 & 5.6 & 34.6 & 17.2 & 21.1 \\
\hline Kujawsko-Pomorskie & 44.1 & 1.2 & 63.1 & 6.6 & 30.2 & 16.7 & 23.1 \\
\hline Warminsko-Mazurskie & 37.7 & 1.3 & 64.0 & 8.7 & 27.3 & 18.7 & 23.6 \\
\hline Pomorskie & 47.9 & 1.4 & 67.1 & 3.0 & 29.9 & 20.0 & 23.7 \\
\hline Nord-Vest & 24.0 & 7.1 & 52.3 & 13.2 & 34.6 & 18.9 & 21.4 \\
\hline Centru & 26.9 & 6.6 & 47.8 & 11.6 & 40.6 & 20.5 & 20.8 \\
\hline Nord-Est & 18.1 & 6.1 & 50.7 & 16.5 & 32.8 & 15.8 & 20.6 \\
\hline Sud-Est & 23.2 & 6.8 & 49.3 & 14.2 & 36.4 & 22.4 & 18.3 \\
\hline Sud - Muntenia & 20.9 & 8.2 & 44.4 & 14.6 & 41.1 & 19.4 & 17.1 \\
\hline Bucuresti - Ilfov & 56.4 & 9.3 & 69.7 & 0.7 & 29.6 & 35.6 & 33.3 \\
\hline Sud-Vest Oltenia & 21.6 & 6.9 & 45.1 & 14.1 & 40.8 & 18.1 & 19.5 \\
\hline Vest & 26.8 & 8.3 & 51.1 & 12.4 & 36.4 & 20.2 & 21.2 \\
\hline Vzhodna Slovenija & 67.2 & 1.5 & 53.4 & 4.3 & 42.3 & 25.3 & 18.3 \\
\hline Zahodna Slovenija & 94.4 & 1.8 & 69.8 & 1.5 & 28.6 & 25.3 & 25.2 \\
\hline Bratislavský kraj & 108.7 & 5.6 & 75.0 & 1.0 & 24.0 & 24.5 & 29.2 \\
\hline Západné Slovensko & 47.4 & 4.9 & 47.7 & 5.7 & 46.6 & 25.9 & 20.0 \\
\hline Stredné Slovensko & 41.3 & 4.6 & 57.4 & 5.4 & 37.2 & 27.6 & 21.9 \\
\hline Východné Slovensko & 37.7 & 3.9 & 59.5 & 4.9 & 35.6 & 27.3 & 22.6 \\
\hline Sjeverozapadna Hrvatska & 60.9 & 3.2 & 66.4 & 4.3 & 29.3 & 23.8 & 20.3 \\
\hline $\begin{array}{l}\text { Sredisnja i Istocna } \\
\text { (Panonska) Hrvatska }\end{array}$ & 37.8 & 2.4 & 56.5 & 16.4 & 27.1 & 23.4 & 16.5 \\
\hline Jadranska Hrvatska & 47.8 & 3.1 & 68.7 & 4.1 & 27.2 & 28.7 & 17.8 \\
\hline
\end{tabular}

